\title{
KONSEP FIQH SEMASA DALAM PEMBINAAN TAMADUN ISLAM MALAYSIA: ANALISIS KRITIKAL
}

\author{
Rahimin Affandi Abd. Rahim* \\ Paizah Ismail ${ }^{* *}$ \\ Shamsiah Mohamad ${ }^{* * *}$ \\ Nor Hayati Md Dahlal ${ }^{* * * *}$
}

\begin{abstract}
There are theories stated that human history normally involved with three dimensions, i.e. the past, present and future. Basically, most historians will prefer to describe the past human civilization without extended it to the present time. Therefore, this article will try to describe the contribution that can be played by the concept of jurisprudence in the development of the Malay-Muslim civilization. It is divided into several sections: First, an introduction to selected theories related to the focus of the study. Second, the concept of contemporary figh and its relationship with the resurgence of Islamic consciousness. Third, the contribution of contemporary figh in catalyzing Islamic civilization in Malaysia, and finally the study will be concluded with various suggestions.
\end{abstract}

Keyword: Contemporary Fiqh, Muslim Civilization, Usul alFiqh, Syafi 'i, Taqlid

\footnotetext{
* Profesor Madya, Jabatan Fiqh \& Usul, Akademi Pengajian Islam, Universiti Malaya, Kuala Lumpur.

** Profesor Madya, Kuliyyah Undang-undang Ahmad Ibrahim, Universiti Islam Antarabangsa Malaysia, Kuala Lumpur.

*** Profesor Madya, Jabatan Fiqh \& Usul, Akademi Pengajian Islam, Universiti Malaya, Kuala Lumpur.

${ }^{* * * *}$ Pembantu Penyelidik, Jabatan Fiqh \& Usul, Akademi Pengajian Islam, Universiti Malaya, Kuala Lumpur.
} 


\section{PENGENALAN}

Pada kebiasaannya, apabila membincangkan tentang sesuatu tamadun, sesetengah sarjana akan mengambil sikap simplistic dalam dua keadaan. Pertama, melihat sesuatu tamadun itu dari sudut dimensi telah lalu tanpa mengaitkannya dengan realiti zaman sekarang dan akan datang. Hal ini amat malang sekali, memandangkan umat Islam amat memerlukan usaha membangunkan dimensi sekarang dan akan datang berpandukan kepada dimensi telah lalu. Tindakan yang terlalu asyik dan mendewa-dewakan dimensi telah lalu, sedikit sebanyak telah menyebabkan umat Islam leka dan gagal memanfaatkan sebahagian besar precedent silam untuk tujuan membangunkan tamadun Islam moden. Kedua, usaha melihat tamadun itu dari sudut elemen material semata-mata sehingga melupakan elemen spiritual yang merupakan teras dan punca utama kekuatan sesuatu tamadun. Apa yang boleh dikategorikan dengan elemen spiritual ini adalah berupa idea, formula, paradigma dan pemikiran yang menjadi tunjang kepada pembentukan sesuatu tamadun.

Berasaskan kepada latar belakang ini, kertas kerja ini bakal mengambil pendekatan yang optimistic dengan meneliti sumbangan yang boleh dimainkan oleh konsep fiqh semasa (KFS) sebagai formula dan paradigma pemikiran di dalam usaha membentuk tamadun Melayu-Islam moden di Malaysia.

\section{TEORI TENTANG TAMADUN ISLAM DAN KAITANNYA DENGAN KONSEP FIQH ISLAM SEMASA}

Sebagai premis awal perbincangan, kajian ini akan memberikan beberapa teori utama yang berkaitan secara langsung dengan fokus kajian; kepentingan sistem fiqh Islam semasa dalam perkembangan tamadun Islam. Terdapat beberapa teori besar (Grand theory) yang menerangkan tentang hal ini iaitu;

Pertama, teori agama dan budaya ilmu sebagai asas pembentukan sesuatu tamadun dunia. Agama memberikan sistem nilai dan garis panduan tentang apa yang boleh dan harus dijauhi untuk diamalkan oleh anggota masyarakat. Sesuatu tamadun dunia yang tidak berdasarkan kepada pengamalan budaya ilmu tidak 
akan kekal lama. Budaya ilmu ini perlu diamalkan pada peringkat kognitif, afektif dan psikomotor. Mengikut Wan Mohd Nor Wan Daud, budaya ilmu ini dapat dicerakinkan di antaranya sebagai ${ }^{1}$;

1. Tindakan menjadikan pencarian ilmu itu sebagai matlamat utama kehidupan melebihi semua matlamat lain seperti matlamat mencari harta benda dan pengaruh.

2. Tindakan yang menghargai semua bentuk ilmu pengetahuan samada ianya tergolong dalam ilmu fardu ain ataupun fardu kifayah.

3. Tindakan yang menghargai semua bentuk sumber ilmu merangkumi sumber wahyu, alam semesta, diri manusia sendiri dan juga akal yang waras serta terpimpin.

4. Terlibat secara langsung dalam proses pengajaran, pembelajaran daan penyebaran ilmu pengetahuan.

5. Bertindak mengikut perkiraan ilmu yang benar dan bukannya mengikut dorongan ilmu yang salah serta hawa nafsu.

6. Pencapaian ilmu perlu dijelmakan dalam bentuk praktikal melalui akhlak yang mulia. Tidak ada gunanya, seseorang itu memperolehi pencapaian akademik yang tinggi seandainya tidak mempunyai akhlak yang mulia.

7. Bersikap hormat-kritis terhadap pandangan sarjana silam dengan perkiraan dan neraca kebenaran yang berteraskan sumber wahyu.

8. Bersikap selektif terhadap semua bentuk ilmu pengetahuan menggunakan pendekatan tauhid.

9. Bertindak mengamalkan semua ilmu yang dimiliki secara bersepadu.

10.Budaya ilmu mendapat dokongan penuh pihak kerajaan di dalam setiap dasar negara.

Wan Mohd Nor Wan Daud (1990), "Budaya Ilmu Sebagai Asas Pembangunan Tamadun", dalam Jurnal Pendidikan Islam, v. 3, bil. 1, hh. 51-67. 
Lebih mendalam lagi, budaya ilmu ini hanya akan berkembang dengan wujudnya kaedah penyelidikan ilmiah yang bermutu tinggi. Ianya dapat digunakan bagi tujuan;

a. menyelesaikan sesuatu masalah (sosial, ekonomi, politik dan ketenteraan) yang dihadapi oleh anggota masyarakat. ${ }^{2}$

b. Menyediakan kerangka paradigma berfikir yang betul sehingga proses penguasaan dan penerokaan bidang ilmu baru dapat dijalankan. ${ }^{3}$

c. Menyediakan proses reviewing (muhasabah) terhadap sesuatu pencapaian tamadun. ${ }^{4}$

Kita boleh memberikan beberapa contoh yang menunjukkan peranan kaedah penyelidikan dalam pembentukan tamadun dunia;

1. Ibn khaldun telah mengasaskan kaedah penyelidikan disiplin sosiologi dan sejarah - boleh dipergunakan bagi memastikan kejayaan kepada program pembangunan masyarakat. Ilmu sosiologi adalah bagi mengkaji struktur sosial dan elemen sosio-politik dan ekonomi di dalam sesuatu masyarakat. Bagi ilmu sejarah pula, beliau menekankan kepentingan ilmu sejarah untuk umat manusia, yang merangkumi persoalan manafaat dan disiplin yang harus dijaga oleh seseorang ahli sejarah. Lebih lanjut lagi, kedua-dua ilmu ini boleh membantu seseorang mengetahui tentang jatuh dan bangun sesuatu tamadun manusia. Ianya dapat dilihat dari segi usia sesuatu tamadun dan faktor-faktor yang menyumbang ke arah kecemerlangan dan kemunduran sesuatu tamadun. Ringkasnya, kedua ilmu ini dapat membantu sarjana Islam

2 Rahimin Affandi Abd Rahim (2000), "Etika Penyelidikan Islam: Suatu Analisa", dalam Jurnal Afkar, v. 1. Kuala Lumpur: Akademi Pengajian Islam.

3 Anis Ahmad (1988), "The Reorientation Of Islamic History : Some Methodological Issues", dalam Islam: Source And Purpose Of Knowledge. Virginia: IIIT, hh. 292-293.

4 Hashim Musa (2004), Pemerkasaan Tamadun Melayu Malaysia Menghadapi Globalisasi Barat. Kuala Lumpur: Penerbit UM. 
menajamkan daya artikulasi mereka terhadap permasalahan ummah Islam dengan lebih holistik. ${ }^{5}$

2. Ibn Rushd, yang membawa paradigma pemikiran saintifik untuk ilmu sains dan teknologi (S\&T) moden telah mempengaruhi perkembangan Renaisance (kesedaran baru berasaskan pembangunan ilmu saintifik) di dalam masyarakat barat. $^{6}$

Kedua, teori asabiyyah di dalam pembentukan tamadun. Antara lainnya teori ini menegaskan masyarakat sebagai suatu organism yang bersifat hidup, mempunyai potensi untuk berubah dan berkembang maju seandainya perancangan pembangunan yang rapi dan tersusun dapat dilakukan. Ianya juga menegaskan bahawa proses pembangunan sesuatu tamadun bergantung kepada nisbah perpaduan sejati di dalam masyarakat berasaskan kepada gabungan antara semangat Asabiyyah dan agama. ${ }^{7}$ Apa yang dapat difahami, dinamika sesuatu tamadun itu akan lebih terjamin seandainya program pembangunan didasarkan kepada usaha yang mementingkan nilai semasa dan ciri-ciri tempatan bagi menangani persoalan hidup. ${ }^{8}$ Proses penyediaan model penyelesaian masalah (seperti konsep fiqh Islam) bagi sesuatu masyarakat bukanlah bersifat monolitik dan seragam sifatnya. Tetapi elemen kontekstual (ciri tempatan) perlu sentiasa diambilkira. Contohnya, paradigma fiqh Hijaz mesti berbeza dengan fiqh Iraq, yang disebabkan oleh faktor perbezaan mentaliti, budaya dan ciri budaya tempatan yang berbeza.

Setiap masyarakat dalam semua generasi pasti akan mempunyai permasalahannya yang tersendiri. Ianya dianggap sebagai cara Allah untuk menguji dan mengalakkan anggota masyarakat mempergunakan akalnya bagi menyelesaikan permasalahan

$5 \quad$ Saleh Faghizadeh (2004), Sosiologi Sosiologi, Mohd Fauzi Yaacob (terj.). Kuala Lumpur: ITNMB, hh.15-118.

6 Hassan Ahmad (2006), Memperkasa Bangsa Melalui Kekuatan Dalaman: Ke Arah Kelahiran Melayu Glokal. Kuala Lumpur: Alaf 21, hh. 250-258.

7 Mohd Kamil Abd Majid (2009), "Perubahan Sosial Dan Impaknya Terhadap Pembangunan Modal Insan Menurut Ibn Khaldun", dalam Jurnal Hadari, v. 1, hh. 45-76.

8 Toto Suharto (2003), Epistemologi Sejarah Kritis Ibn Khaldun. Yogyakarta: Fajar Pustaka Baru, hh. 87-103. 
tersebut. Lebih mendalam lagi, Islam amat menekankan pendekatan world affirmative (dunia sebagai tempat berguna untuk mendapatkan bekal hari akhirat) dan societal (mementingkan penjagaan aspek kemasyarakatan). Berasaskan pendekatan ini, jalan penyelesaian masalah kontekstual ini perlu didasarkan kepada sumber wahyu dan akal yang terpimpin. ${ }^{9}$

Ketiga, teori jiwa hamba yang dimiliki oleh bangsa yang pernah dijajah, yang kebiasaannya akan menganggap kuasa penjajah sebagai suatu bangsa yang maju dan agung. Dalam konteks Malaysia, penjajahan kuasa penjajah British selama lebih 450 tahun telah meninggalkan kesan penjajahan epistemologi di kalangan masyarakat Malaysia. ${ }^{10}$ Hasilnya, walaupun kuasa penjajah telah meninggalkan Malaysia, namun saki baki epistemologi barat masih lagi kekal di kalangan sesetengah penganut Islam di Malaysia. Pengaruh ini boleh dilihat dari segi paradigma mereka memandang syariah Islam. Bagi mereka syariah Islam dianggap ketinggalan zaman dan ianya perlu ditolak ataupun diubah pemakaiannya mengikut neraca sekularisme barat. ${ }^{11}$

Oleh yang demikian, dalam usaha memperkenalkan KFS ini adalah satu langkah memperbaiki pemikiran yang telah rosak dijajah. Ia diperlukan sebagai usaha ijtihad pemikiran yang tinggi bagi menyelesaikan permasalahan yang timbul dalam masyarakat.

\section{KONSEPASAS FIQH SEMASA: SATU PENGENALAN}

Pada dasarnya dapat dilihat dari segi susunan konsepnya, gagasan fiqh semasa ini ialah suatu percubaan untuk menyediakan sistem

9 Zakaria Stapa (2009), Manusia Pembina Tamadun: Perspektif Pemikiran Islam", dalam Jurnal Hadari, v. 1, hh. 31-42.

10 Syed Hussein al-Attas (2005), "Watak Tertawan Di Negara Membangun", dalam Mohamad Daud Mohamad (ed.), Pascakolonialisme Dalam Pemikiran Melayu. Kuala Lumpur: DBP, hh. 2-7.

11 Rahimin Affandi Abd Rahim (2006), "Islam Dan Isu Penterjemahan Dalam Era Globalisasi”, dalam Hamedi Mohd Adnan (ed.), Penerbitan Malaysia-Indonesia: Mengukuhkan Jaringan Penerbitan Serantau. Kuala Lumpur: Penerbit UM, hh. 151-164. 
fiqh Islam yang difikirkan paling sesuai untuk masyarakat Malaysia. Dari sudut pemahaman asasnya, konsep ini mempunyai beberapa intipati penting. Pertama, ia tercetus daripada usaha pembaharuan (tajdīd) undang-undang Islam demi untuk menjadikannya sebagai sebuah undang-undang yang bersifat syumul, hidup dan proaktif walaupun terpaksa berhadapan dengan perubahan semasa masyarakat. Kedua, ia bukan sebuah konsep yang longgar dan liberal di pandang dari sudut pengajian hukum Islam. Sebaliknya, ia cuba untuk menghidupkan kembali peranan fuqaha dengan penggunaan kaedah $u$ sul $a l-f i q h^{12}$ dalam beberapa aspek iaitu:

1. Proses menilai pandangan fuqaha klasik agar ianya bersesuaian dengan realiti semasa.

2. Proses menilai, mengubah dan melakukan ijtihad terhadap permasalahan semasa di Malaysia ${ }^{13}$ yang tiada jawapan daripada nas-nas al-Quran dan al-Sunnah, dan kitab fiqh klasik. Lebih tepat lagi, ianya bukan bersifat umum dan retorik semata-mata, bahkan turut menyediakan alternatif lengkap dan terperinci.

3. Proses mengenal pasti dan mewujudkan database Malaysia terutamanya dalam, pertama, gambaran yang lengkap tentang realiti semasa Malaysia dari segi latarbelakang sejarah,

12 Mahmood Zuhdi Abdul Majid (1999), "Hukum Islam semasa bagi Masyarakat Malaysia yang membangun", dalam Abdul Karim Ali \& Raihanah Azhari (eds.), Hukum Islam Semasa Bagi Masyarakat Malaysia Yang Membangun. Kuala Lumpur: Akademi Pengajian Islam, Universiti Malaya, hh. 4-5.

13 Raihanah Abdullah (1999), "Pegawai Syariah Wanita di Mahkamahmahkamah Syariah di Malaysia", dalam Abdul Karim Ali \& Raihanah Haji Azhari (ed.), Hukum Islam Semasa Bagi Masyarakat Malaysia Yang Membangun. Kuala Lumpur: Akademi Pengajian Islam, Universiti Malaya, hh. 221-232; Anisah Ab. Ghani (1999), "Batasbatas pergaulan antara lelaki dan perempuan dalam masyarakat Islam kini: Satu Huraian Hukum Islam Semasa", dalam Abdul Karim Ali \& Raihanah Azhari (ed.), Hukum Islam Semasa Bagi Masyarakat Malaysia Yang Membangun. Kuala Lumpur: Akademi Pengajian Islam, Universiti Malaya, hh. 239-248. 
struktur sosial, politik, ekonomi dan beberapa isu semasa. ${ }^{14}$ Keduanya; keperluan mendalami ilmu-ilmu moden selain dari bidang hukum Islam seperti ilmu sains sosial, budaya, ekonomi, perubatan, politik dan sebagainya. Kewujudan database Malaysia ini dapat dijadikan panduan untuk membantu fuqaha menghasilkan proses penentuan hukum yang bersifat semasa. ${ }^{15}$

4. Proses menyediakan kaedah-kaedah dan metodologi asas di dalam ilmu usul al-fiqh yang dapat membantu gologan fuqaha menyelesaikan persoalan baru di Malaysia. Antara metodologi berkaitan yang kerap digunakan adalah kaedah 'urf, ijtiḥàd jamā' $\bar{i}$, tarjīh, talfiq, ijmā', maqāșid al-shari'‘ ah, mașlahah, Siyāsah Shar'iyyah" dan sebagainya.

\section{SUMBANGAN KONSEP FIQH SEMASA KE ARAH PEMBINAAN TAMADUN ISLAM DI MALAYSIA}

Berasaskan kepada tiga grand theory yang dinyatakan dalam bahagian di atas, kita dapat mengesan beberapa sumbangan penting yang telah dimainkan oleh KFS ini dalam usaha pembentukan tamadun Islam di Malaysia. Kesemuanya membabitkan pemakaian paradigma keilmuan dan pemikiran Islam yang lebih bersifat progresif. Antaranya;

Pertama, KFS merupakan usaha tajdid dalam bentuk yang lebih praktikal bagi menghakis dominasi taqlid dalam pengajian Islam di Malaysia. KFS berusaha untuk menghapuskan budaya

14 Abdullah Alwi Hassan (1999), "Permasalahan Intelektual Dalam Pembinaan Hukum Islam Semasa Di Malaysia", dalam Abdul Karim Ali \& Raihanah Azhari (ed.), Hukum Islam Semasa Bagi Masyarakat Malaysia Yang Membangun. Kuala Lumpur: Akademi Pengajian Islam, Universiti Malaya, hh. 125-130.

15 Mahmood Zuhdi Abdul Majid (1999), Hukum Islam Semasa, hh. 5-6.

16 Kesemua perbincangan yang agak detail tentang kaedah-kaedah ini ada diterangkan oleh serangkaian tokoh tempatan di dalam bahagian metodologi, lihat Abdul Karim Ali \& Raihanah Azhari (ed.) (1999), Hukum Islam Semasa Bagi Masyarakat Malaysia Yang Membangun. Kuala Lumpur: Akademi Pengajian Islam Universiti Malaya. 
taqlid yang menyebabkan kelesuan sistem fiqh Islam berhadapan proses pemodenan. ${ }^{17}$ Dalam kurikulum pengajian keilmuan Islam subjek fiqh Islam seolah-olah telah dianggap sebagai pelajaran sejarah perundangan Islam semata-mata yang bukan lagi mampu menanggani situasi semasa. ${ }^{18}$ Fiqh sudah begitu lama dibiarkan beku serta statik, dan ini telah menyebabkan banyak persoalan hidup masyarakat tidak menepati kehendak syara' yang sebenar. ${ }^{19}$ Sikap beku, jumud dan taqlid di kalangan fuqaha yang sepatutnya bertindak sebagai inteligensia Muslim membangun sistem fiqh yang up to date telah menimbulkan beberapa kesan buruk, ${ }^{20}$ seperti wujudnya:

1. Kekosongan fikiran yang berbentuk ilmu. Kekosongan ini kemudiannya telah direbut atau diambil peluang oleh aliran politik luar seperti Komunisme, Sekularisme dan sebagainya.

2. Kesempitan dalam pelaksanaan hukum Islam iaitu terbatas kepada bidang undang-undang kekeluargaan sahaja.

3. Menjadi sebab lahirnya tindakbalas yang berlebihan dari sesetengah pihak sehingga mereka mahu mengikut model barat secara mutlak tanpa menilai kesesuaiannya dengan lunas-lunas Islam dan perkiraan ketimuran.

Atas dasar ini, demi menghapuskan ketiga-tiga elemen yang terhasil akibat dari kelesuan dan kegagalan sistem fiqh, kita terpaksa mengambil sikap proaktif dengan membangunkan sistem fiqh Islam yang bersifat semasa dalam institusi membabitkan pengajian keilmuan Islam yang bermatlamatkan; Pertama, melatih

17 Taha Jabir al-Alwani (1991), "Taqlid And The Stagnation Of The Muslim Mind", dalam The American Journal of Social Sciences, v. 8 , no. 3 , h. 513 .

18 Rahimin Affandi Abdul Rahim (1995), "Budaya Taqlid di Dalam Masyarakat Melayu: Satu Tinjauan Ringkas", dalam Jurnal Syariah, v. 3, bil. 1. Kuala Lumpur: Akademi Pengajian Islam, Universiti Malaya, hh. 30-32.

19 Muhammad Nabil Muhammad Syukri (2000), “Pembaharuan Fiqh : Keperluan Dan Metodologi”, dalam Pengasoh, bil. 562, h. 57.

20 Rahimin Affandi Abdul Rahim (1997), "Gerakan Tajdid di Malaysia: Teori dan realiti", dalam Dinamisme Pengajian Syariah. Kuala Lumpur: Berita Publishing Sdn. Bhd., hh. 102-103. 
pelajar untuk menganalisis institusi Islam dan kaitannya dengan realiti semasa, berbanding dengan sistem pengajian ala taqlid silam yang menggunakan pendekatan yang tidak kritikal, tertutup dan berasaskan latarbelakang yang bukan bersifat Malaysia. ${ }^{21}$ Kedua, bentuk pengajian fiqh Malaysia ini dapat dijadikan sebagai asas utama untuk menyediakan infranstruktur intelektual sebelum sesuatu cita-cita negara Islam boleh tercapai. ${ }^{22}$ Ketiga, dapat menunjukkan ciri-ciri kesempurnaan yang terkandung di dalam sistem penyelesaian fiqh Islam yang merangkumi keperluan menjaga kepentingan hubungan dengan Allah, sesama makhluk dan hubungan manusia dengan alam persekitaran.

Kedua, KFS dalam mekanisme asasnya amat mementingkan penggunaan kaedah penyelidikan hukum Islam yang agak ketat. Seandainya elemen ini kurang dititik beratkan, kita dapat menjangkakan bagaimana nisbah negatif yang bakal terkena kepada sistem fiqh Islam. Ianya bakal menyemarakan lagi budaya taqlid yang memang begitu berakar di dalam masyarakat Islam semasa. KFS berusaha mengalakkan penyelidikan hukum Islam berasaskan konsep fiqh semasa di kalangan ahli akademik dan pelajar pasca siswazah. Terpenting sekali, ianya perlu membabitkan realiti praktis apa yang berkembang di dalam masyarakat dan sesuatu institusi agama yang disertakan pula dengan alternatif pilihan. ${ }^{23}$ Mengikut Mahmood Zuhdi Abd. Majid, kajian di peringkat pasca siswazah ini boleh dianggap sebagai penyelidikan semi ijtihad yang perlu membabitkan pelbagai masalah hukum Islam yang timbul di dalam masyarakat. Atas dasar ini, standard ataupun mutu

$21 \quad$ Ibid., h. 106.

22 Mohd Kamil Ab. Majid (1993), "Sejarah perkembangan penulisan hukum Islam di Malaysia: Tumpuan khusus di negeri Kelantan", dalam Jurnal Syariah, v. 1, bil. 1. Kuala Lumpur: Akademi Pengajian Islam, Universiti Malaya, hh. 86-89.

23 Norhashimah. Mohd Yasin (1994), Islamisation or Malaynisation: A study on th.e role of Islamic law in th.e economic development of Malaysia: 1969-1993, (Tesis Ph.D untuk School of Law, University of Warwick, England); Ahmad Hidayat Buang (1997), "Muamalat di Malaysia: Suatu Tajdid Atau Reaksi Pasaran", dalam Dinamisme Pengajian Syariah. Kuala Lumpur: Berita Publishing Sdn. Bhd., hh. 107-124; Rahimin Affandi Abdul Rahim (1999), Islamic Legal Reform In The Administration Of Islamic Law In Malaysia: A Critical Analysis, (Tesis Ph.D, University of Birmingham). 
penyeliaan yang rapi dan ketat oleh ahli akademik yang kompeten perlu ditetapkan kepada setiap pelajar yang terbabit. ${ }^{24}$

Ketiga, KFS berusaha melanjutkan usaha penggilapan dan pemahaman fiqh sebenar. Memandangkan unsur-unsur kemanusiaan (kefahaman) terlibat di dalam fiqh, maka sepanjang zaman harus ada usaha menggilap semula unsur pemahaman berkenaan kerana pemahaman suatu generasi tentunya tidak sama dengan generasi yang mendatang, ${ }^{25}$ Dalam soal ini, al-Quran dan al-Sunnah sebagai pedoman utama untuk kejayaan hidup di dunia dan akhirat telah menetapkan suatu pandangan yang cukup dinamis tentang kehidupan manusia. Hal ini dijelaskan oleh Muhammad Iqbal sebagai : "the teaching of the Quran that life is a progressive creation necessitates that each generation, guided but unhampered by the work of its predecessors, should be permitted to solve its own problems." ${ }^{26}$ Dinamisme pandangan al-Quran ini antara lainnya menegaskan bahawa setiap generasi perlu diberi kebebasan untuk menentukan hidup mereka sendiri dan menyelesaikan masalah sendiri dengan pertunjuk fuqaha sebelumnya, tetapi tidak sampai kepada taqlid membuta tuli, membiarkan jawapan terhadap masalah masa kini ditentukan oleh fuqaha yang sebelumnya. ${ }^{27}$

Peluasan peranan fuqaha untuk setiap zaman ini antara lainnya bertujuan untuk; pertama, memperbetulkan segala bentuk kelemahan dan keburukan yang selama ini dinisbahkan kepada syariah Islam, ${ }^{28}$ dan membuktikan idea kemajuan yang

24 Rahimin Affandi Abd Rahim, "Isu Pendekatan di dalam Pengajian Syariah di Malaysia: Satu Telaah Awal", dalam Jurnal Syariah, v. 13, bil. 1, 2005, hh. 105-134.

25 E. Ezzati (1970), An Introduction To Shi'i Islamic Law And Jurisprudence. Lahore, hh. 99-100.

26 Muhammad Iqbal (1982), Reconstruction Of Religious Thought In Islam. Lahore, h. 168.

27 Abu Bakar al-Ash'ari (1954), Kemerdekaan Berfikir Dalam Islam. Penang, h. 54.

28 Mahmood Zuhdi Abd. Majid (1998), "Pengajian Syariah: Satu Pentakrifan", dalam Dinamisme Pengajian Syariah. Kuala Lumpur: Berita Publishing Sdn. Bhd., hh. 6-10. 
terkandung di dalam Islam. ${ }^{29}$ Keduanya, mengingatkan fuqaha bahawa mereka patut menjadi agen perubahan yang bersikap prihatin dan proaktif dengan isu-isu semasa yang timbul di dalam masyarakat. ${ }^{30}$ Bersesuaian dengan tugas fuqaha sebagai pewaris nabi-nabi, sepatutnya tugas mereka bukan terhad kepada menjadi penyaksi kepada peristiwa sejarah di zamannya, tetapi apa yang lebih penting lagi mereka patut menjadi tenaga utama yang mengerakkan peristiwa sejarah tersebut dengan menganalisis permasalahan semasa dan mengemukakan jawapan yang terbaik. ${ }^{31}$

Keempat, KFS berusaha untuk berpegang kepada prinsip alAṣălah wa al-Mu 'ạṣarah (mengekalkan warisan turath silam dan mengambilkira elemen pemodenan). Dalam soal ini, umat Islam perlu menjaga warisan tradisi yang berupakan formula susunan sarjana Islam silam dan berusaha membangunkan tamadun terkini berasaskan adunan intipati tradisi ini dengan elemen pemodenan. Contoh terbaik yang boleh diberikan adalah kajian ilmiah di peringkat pasca siswazah APIUM yang mengkaji status rawatan kumbahan air yang diamalkan oleh Indah Water Konsortium. Dalam kajian ini, Nadzirah Ismail telah menggunakan prinsip al-Aṣalah wa al-Mu 'assarah, apabila meneliti pandangan fuqaha silam yang berkaitan dengan status dan bahan yang menyucikan air-yang dikaitkan pula dengan kaedah teknologi rawatan kumbahan air yang terkini. Hasilnya, beliau mendapati status air kumbahan yang dirawat ini benar-benar bersih dan bertaraf air mutlaq, yang boleh digunakan untuk keperluan seharian oleh kalangan pengguna Islam. ${ }^{32}$

Sedapat mungkin KFS cuba mengaplikasikan prinsip wasatiyyah (pertengahan) dalam pengamalan keilmuan. Dalam dunia akademik, prinsip wașatiyyah ini boleh digunakan sebagai

29 Muhammad Abu Bakar (1982), Penghayatan Sebuah Ideal. Kuala Lumpur, hh. 27-53.

30 Mahmood Zuhdi Abd. Majid (1997), Pengantar Undang-Undang Islam Di Malaysia. Kuala Lumpur, hh. 34-40.

31 Mohd Kamil Ab. Majid (1999), "Ulama Dan Perubahan Social Dalam Islam", dalam Jurnal Usuluddin, bil. 10. Kuala Lumpur: Akademi Pengajian Islam, Universiti Malaya, hh. 84-93.

32 Nadzirah Ismail (2003), Status Kesucian Air Kumbahan Yang Dirawat Melalui Kaedah Rawatan Oleh Indah Water Konsortium (Tesis Sarjana, Jabatan Fiqh dan Usul, APIUM). 
salah satu alat untuk menilai, menganalisa dan menerima sesuatu pandangan yang dikemukakan oleh pihak lain, tanpa terpengaruh dengan kecenderungan si penilai itu sendiri (Pre Conceived Idea). Dalam amalan keilmuan Islam, sesuatu khabar, riwayat, teori, pandangan, formula dan apa-apa dapatan kajian yang dilahirkan perlu dinilai secara kritikal, futuristic, berpandangan jauh dan terpenting sekali perlu mengambilkira prinsip wasatiyyah ini. Ianya boleh dikatakan sebagai suatu tindakan adil (bertindak sebagai orang tengah) dalam menilai sesuatu perkara. Melalui pemakaian prinsip ini, sesuatu pandangan yang diteliti perlu mengambil kira beberapa perkara penting;

1. Mengambil sikap selektif (tidak menerima dan menolak secara melulu), yang menuntut ianya dilihat secara holistik (menyeluruh). ${ }^{33}$

2. Memastikan ketepatan sesuatu berita atau teori itu didapati daripada sumber yang tepat dan betul, seperti mana penegasan Allah agar kita mengamalkan sikap berhati-hati terhadap berita yang dibawa oleh orang fasiq, kerana ianya akan membawa fitnah yang bakal merosakkan kehidupan. Untuk tujuan pengesahan, ianya perlu dinilai dan dikritik secara luaran dan dalaman. Kritikan luaran bertujuan untuk menentukan ketulenan dan keaslian sesuatu sumber tersebut. (kajian sanad) ${ }^{34}$ Manakala kritikan dalaman pula bertujuan untuk memastikan kemunasabahan dan kewarasan isi kandungan sesuatu sumber itu dinilai dari perspektif Islam. (kajian matan). ${ }^{35}$

3. Melihat keserasian sesuatu hujah yang dipakai dengan pandangan sumber yang berautoriti, samada ianya daripada nas Wahyu (al-Quran dan al-Sunnah), fakta sejarah ataupun

33 Rahimin Affandi Abd Rahim (2000), "Etika Penyelidikan Islam: suatu analisa", dalam Jurnal Afkar, v. 1. Kuala Lumpur: Akademi Pengajian Islam, Universiti Malaya, hh. 177-196.

34 Maklumat Lanjut boleh didapati dalam Che Cob Che Mat (1996), Kriteria Penerimaan Dan Penolakan Hadith: Satu Kajian Perbandingan Antara Ahl Al-Sunnah Dan Shi'ah (Tesis Untuk Fakulti Sastera Dan Sains Sosial, Universiti Malaya), h. 482-535.

35 Ibid., hh. 642-657. 
teori serta aksioma pemikiran yang telah diterima ramai (seperti terkandung dalam konsep ijma dan tawattur). ${ }^{36}$

4. Tidak boleh menyalahi dengan apa yang telah ditetapkan secara Qat'i oleh sumber Quran dan sunnah, manakala sesuatu warisan silam yang dihasilkan melalui pemikiran manusia berasaskan kepada sumber akalnya sendiri baik dari segi pentafsirannya terhadap nas ataupun responnya terhadap situasi sosial yang timbul di zamannya-perlu dinilai secara kritikal, kerana ianya masih bertaraf zanni, yang perlu sentiasa diulangkaji dan diperlengkapkan oleh setiap sarjana di setiap zaman. ${ }^{37}$

5. Perlu menolak pendekatan kajian dan penilaian Islam yang bersifat legal formalistik. (hitam ataupun puteh) yang akan menghasilkan kajian yang bersifat kaku dan cenderung kepada tindakan menghukum dan bukannya bersifat konstruktif bagi tujuan dakwah mendidik golongan sasaran kajian, anggota masyarakat. Sebaiknya, sarjana Islam perlu memikirkan untuk menggunakan pendekatan kajian yang lebih terbuka dan holistic (menyeluruh) dalam proses penilaian sesuatu objek kajian. ${ }^{38}$

Dalam soal pengaplikasian prinsip wasatiyyah ini, KFS sebagai contohnya telah mengambil sikap pertengahan di antara pandangan golongan Salafi dan liberalis. Bagi golongan Salafi, mereka terlalu menentang pemodenan barat secara melampau, dan golongan liberalis pula terlalu taasub dengan semua formula dan epistemologi keilmuaan barat sehingga sanggup memperkecilkan sebahagian warisan fuqaha silam yang muktabar.

Kelima, KFS menekankan keperluan untuk mengenalpasti garis panduan ataupun piawaian pendekatan yang bersesuaian dengan

36 Rahimin Affandi Abd Rahim (1993), “The Concept Of Ijma' In Islamic Law: A Comparative", dalam The Journal of Hamdard Islamicus. Pakistan, v. 16, hh. 91-104.

37 Rahimin Affandi Abd Rahim (2002), "Epistemologi Hukum Islam: satu pengenalan", dalam Jurnal Usuluddin, bil. 15, 2002.

38 Rahimin Affandi Abd Rahim (2006), "Ulamak Dan Paradigma Menanggani Kebudayaan Melayu", dalam Hashim Awang, Othman Yatim dan Nor Azita Che Din (eds.), Wacana Budaya. Kuala Lumpur: APMUM, hh. 55-80. 
realiti mayarakat Malaysia semasa di dalam proses pengeluaran sesuatu hukum di dalam sistem fiqh Islam. Antara pendekatan yang dicadangkan;

1. Perlu menghargai keunggulan sentuhan kebudayaan manusia Melayu yang pernah melahirkan tamadun material dan intelektual yang tinggi di rantau Alam Melayu suatu masa dahulu. Ianya merujuk kepada pelbagai nilai positif budaya Melayu seperti;

a. Masyarakat yang ditakdirkan mendiami kawasan iklim sederhana yang kemudiannya telah melahirkan manusia yang berjiwa lembut, berbanding dengan penduduk kawasan iklim yang panas seperti Timur Tengah. ${ }^{39}$ Hal ini terbukti apabila Islam secara mudah telah diterima oleh penduduk Alam Melayu tanpa menumpahkan darah seperti mana yang berlaku di Timur Tengah, Afrika dan Eropah. ${ }^{40}$

b. Masyarakat yang mengamalkan paradigma mesra alam dan mementingkan prinsip penjagaan keseimbangan alam semesta

c. Masyarakat yang mementingkan elemen kesederhanaan di dalam proses berfikir dan bertindak ${ }^{41}$

d. Masyarakat yang mementingkan soal menjaga kerukunan hidup bermasyarakat dan menentang keras sebarang elemen yang bersifat individualism. ${ }^{42}$ Ianya juga dapat

39 Ibn Khaldun (t.t), Muqaddimah Al-'Allāmah Ibn Khaldun. Dar alFikr, hh. 82-95.

40 Rahimin Affandi Abdul Rahim (2003) "Analisis Sejarah. Dakwah. Dan Jalinan Intelektuaal Rantau Malaysia-Indonesia", dalam Zulkiple Abd. Ghani (ed.), Jaringan Dakwah Malaysia-Indonesia. Bangi: Jabatan Pengajian Dakwah Dan Kepimpinan, UKM dan Universitas Muhammadiyah Sumatera Utara (UMSU), hh. 47-74.

41 Abdul Halim Othman Dan Md. Shuaib Che Din (1993), "Sifat Kesederhanaan", dalam Psikologi Melayu. Kuala Lumpur: DBP, hh. 102-109.

42 Norazit Selat (1994), "Nilai Kerja Dalam Masyarakat Melayu", dalam Budi Kencana: Kumpulan Makalah Memperingati Persaraan Profesor Tan Sri Dato' Ismail Hussien. Kuala Lumpur: APMUM, hh. 133-141. 
dirujuk sebagai manusia yang memiliki semangat yang mementingkan kerukunan hidup bermasyarakat (Egalitarian) yang cukup tinggi. ${ }^{43}$ Pendekatan ini bukan terhad kepada anggota masyarakat Melayu semata-mata, bahkan juga kepada masyarakat asing. ${ }^{44}$

e. Masyarakat yang kuat berpegang kepada falsafah yang mementingkan pertimbangan agama dan nilai (perennial and ultimate perspective), berbanding dengan masyarakat barat yang lebih mementingkan persoalan kebendaan dan individualism mengatasi persoalan agama. ${ }^{45}$

f. Manusia yang memiliki kepintaran pemikiran yang cukup advance yang diperincikan dengan empat bentuk pemikiran; (i) Teologis-Rasional, (ii) Alegorikal (simbolik), (iii) Analogis dan pragmatic. ${ }^{46}$

g. Mengamalkan sikap terbuka, sanggup belajar dan selektif terhadap pengaruh budaya dan agama asing. ${ }^{47}$

2. Perlu memaklumi bahawa Islam telah menjadi intipati terpenting ataupun asas jatidiri masyarakat Melayu (teori receptio in complex) sehingga menjadikan sebahagian besar kebudayaan Melayu bertepatan dengan ajaran Islam. Atas dasar ini penilaian yang lebih kondusif dan terbuka perlu digunakan untuk menilai dan menghargai elemen kebudayaan Melayu.

43 Wan Abdul Halim Othman (1993), “Hubungan Kekeluargaan Dalam Masyarakat Melayu”, dalam Psikologi Melayu. Kuala Lumpur: DBP, hh. 61-101.

44 Idris Zakaria (2003), "Islam Dan Amalan Tolenrasi Di Nusantara", dalam Zulkiple Abd Ghani (ed.), Jaringan Dakwah Malaysia Indonesia. Bangi: Jabatan Dakwah. Dan Kepimpinan, UKM, hh. 150-165

45 Abdul Rahman Abdullah (2001), Falsafah Dan Kaedah. Pemikiran. Kuala Lumpur: Utusan Publication, hh. 134-140.

46 Hassan Ahmad (2004), "Bahasa Dan Pemikiran Melayu: Tradisi Dan Kesinambungan”, dalam Worawit Baru@ Haji Ahmad Idris (ed.), Pemikiran Melayu: Tradisi Dan Kesinambungan. Kuala Lumpur : DBP, hh. 1-12.

47 Abdul Rahman Abdullah (1981), Pemikiran Umat Islam Di Nusantara. Kuala Lumpur: DBP, hh. 54-56. 
3. Walaupun masyarakatMelayu merupakan golongan terpenting di Malaysia, berdasarkan penguasaan politik dan pelbagai dasar yang bersifat pro bumiputera, namun masih banyak lagi kelemahan yang dimiliki oleh masyarakat Melayu. Hal ini boleh dilihat dari sector sosio-politik dan ekonomi. Beberapa contoh boleh diberikan, seperti kadar kemiskinan masyarakat Melayu di bandar dan luar bandar yang masih tinggi sehingga menuntut pihak kerajaan menjalankan dasar pembasmian kemiskinan golongan miskin ini yang berterusan, di samping pihak berkuasa Agama juga perlu sentiasa mengambilkira unsur kemiskinan ini di dalam program pengagihan zakat setiap tahun.

4. Nisbah masyarakat majmuk di Malaysia yang sangat rendah dari segi integrasi kaum. Dalam reality ini, api perpecahan agak senang timbul, khususnya yang membabitkan kepentigan sosio, politik dan keagamaan semua kaum di Malaysia. Kita boleh merujuk kepada usaha yang dijalankan oleh NGO tertentu yang memperjuangkan penyebaran faham liberalisme (kebebasan dan hak asasi manusia) dalam setiap perlakuan dan pemikiran manusia. Dalam soal ini, pelbagai syiar dan autoriti Islam dipersoalkan, kerana kesemua autoriti Islam ini dilihat bertanggungjawab menghalang agenda liberalisme ini. Sebagai contohnya, terdapat NGO di Malaysia yang bergiat cergas menimbulkan beberapa isu;

a. Tuntutan IFC (Inter Faith Council) agar pihak kerajaan menyamatarafkan semua pemeluk agama di Malaysia tanpa mengiranya Islam ataupun bukan Islam.

b. Isu yang mencabar dominasi dan keistimewaan hak bumiputera Melayu-Islam - kononnya bertentangan dengan nisbah persamaan hak asasi semua warganegara bukan Islam di Malaysia. Isu yang mencabar konsep jati diri (malayness) Melayu yang sinonim dengan penganut Islam. Sebaliknya isu jati diri Melayu cuba ditolak dengan cara bertolak ansur dan mendokong peluang untuk seseorang Melayu murtad ${ }^{48}$ serta sanggup memberikan

48 Rahimin Affandi Abd Rahim (2006), "Islam dan perkembangan Emosi Melayu Selepas Merdeka: Satu Analisis", dalam Hashim Musa (ed.), Emosi Melayu. Kuala Lumpur: APMUM, hh. 405-425. 
khidmat guaman untuk mempertahankan hak ini. Antara kes yang terlibat adalah kes Ayah Pin, Kumpulan Artikel 11, Lina Joy dan Kamariah Ali. ${ }^{49}$

c. Isu pluralisme agama, yang menganggap semua agama adalah sama di sisi tuhan dan boleh membawa kesejahteraan kepada umat manusia.

d. Isu yang mempersoalkan kesan psikologi dan perundangan yang timbul akibat seseorang penganut agama bukan Islam memeluk agama Islam.

e. Isu menentang cadangan pelaksanaan undang-undang Hudud yang dikatakan ketinggalan zaman dan bakal menindas penganut bukan Islam.

5. Masyarakat di Malaysia amat mudah terpengaruh dengan perkembangan moden yang dibawa oleh arus globalisasi dunia. Memanglah diakui terlalu unsur positif yang dibawa oleh arus globalisasi ini, namun pada masa yang sama juga pelbagai perkembangan fahaman sekularisme yang menyesatkan telah turut sama berkembang pesat sehingga mempengaruhi sejumlah besar masyarakat Malaysia. Bagi menghadapi realiti ini, semua pihak termasuklah kerajaan dan pakar perundangan Islam perlu mengamalkan sikap proaktif dan selektif dengan menyediakan pelbagai elemen mendidik dan pencegahan yang sepatutnya. ${ }^{50}$

6. Perlu mengelakkan sikap yang terlalu politiking dalam menanggani sesuatu isu yang membabitkan kepentingan negara. Ini termasuklah isu permasalahan dalaman negara yang bakal menjejaskan pencapaian pembangunan, yang memerlukan kedua pihak, parti pemerintah dan pembangkang sama-sama bersatu untuk mengatasinya. Hal ini antara lainnya termasuklah isu keruntuhan moral, dadah, peningkatan kadar

49 Ummu Atiyah Ahmad Zakuan (2007), "Hak Asasi Manusia Dan Demokrasi Dari Persepktif Islam Dan Barat", dalam Mohd Izani Mohd Zain (ed.), Demokrasi Dan Dunia Islam: Perspektif Teori Dan Praktik. Kuala Lumpur: Penerbit UM, hh. 106-112.

50 Rahimin Affandi Abd Rahim (2005), "Pendekatan Pluralisme dalam pengajian Islam: Satu pengenalan", dalam Jurnal KATHA. Kuala Lumpur: Pusat Dailog Peradaban UM, v. 2. 
jenayah, keruntuhan rumahtangga orang Melayu, kemiskinan, pengaruh budaya kuning, pencemaran alam, penurunan semangat patriotisme di kalangan muda dan banyak lagi.

Keenam, KFS berusaha memperjelaskan tentang elemen epistemologi hukum Islam di dalam proses penyediaan sistem fiqh semasa. Di dalam sesuatu kajian ilmiah, terdapat suatu pendekatan yang menetapkan bahawa proses pengkajian yang mendalam terhadap sesuatu hakikat ilmu ataupun disiplin tertentu perlu dilihat kepada aspek epistemologi disiplin tersebut. ${ }^{51} \mathrm{Hal}$ ini bersesuaian dengan takrif dan ruang lingkup epistemologi yang menyelidik asal usul, sumber, sifat, kaedah dan had sesuatu ilmu tersebut. ${ }^{52}$ Dalam menghadapi cabaran zaman moden ini, sepatutnya sesuatu pengajian syariah yang diusahakan perlu menitikberatkan persoalan epistemologi hukum Islam yang bakal memberikan gambaran yang jelas kepada penganut Islam dan bukan Islam tentang bagaimana syariah Islam itu bukannya didasarkan kepada kepercayaan dogmatik yang tidak boleh dipertikaikan, tetapi ianya dibina atas dasar yang emperikal, rasional dan mempunyai sumber, sebab musabab dan kaedah yang rapi, sebelum menetapkan sesuatu hukum yang berkaitan dengan persoalan kemanusiaan. ${ }^{53}$

Ianya termasuk juga perlu memperkembangkan elemen ontologi, epistemologi dan aksiologi disiplin usul al-fiqh dengan perkiraan dan keilmuan semasa. ${ }^{54}$ Dengan mengambilkira tiga prinsip utama yang sering ditekankan penggunaannya dalam gagasan fiqh semasa iaitu urf, Maslahah dan ilmu sains social moden, ternyata sekali usaha untuk memperkemaskan elemen epistemologi (sumber dan

51 Fadzulullah Shuib (1995), Kecermelangan Ilmu Dalam Sejarah. Dan Tamadun Islam. Kuala Lumpur, h. 33.

52 Muhammad Zainiy Uthman (2001), "Islam, Sains Dan Pemikiran Objektif: Suatu Perbandingan Ringkas", dalam Jurnal YADIM, bil. 2, November 2001, hh.146-148.

53 Harun Nasution (1989), Islam Rasional: Gagasan Dan Pemikiran. Jakarta, hh. 328-334.

54 Ainurrafiq Dawam (2004), "Menawarkan Epistemology Jama'i Sebagai Epistemology Usul Al-Fiqh: Sebuah. Tinjauan Filosofis", dalam Riyanto (ed.), Neo Usul Fiqh: Menuju Ijtihad Kontekstual. Yogyakarta: Fakultas Syariah Press, hh. 1-23. 
metode) ușūl al-fiqh adalah amat mendesak sekali. Hal ini dapat dilakukan dengan tiga pendekatan yang utama;

1. Mengabungkan (sentesis) di antara ilmu ușül al-fiqh ini dengan keilmuan moden lain (seperti ilmu sains social moden) yang sekali gus bakal melengkapkan lagi kaedah penyelidikan hukum Islam alternatif untuk zaman moden ini. ${ }^{55}$ Walaupun diakui ilmu usul al-fiqh ini memang hebat dan berteraskan world-view Islam sepenuhnya, tetapi untuk konteks zaman moden ini ianya tidak boleh berdiri sendiri dan perlu disokong serta digabungkan dengan disiplin keilmuan lain.

2. Membangunkan kaedah 'Urf Malaysia yang berbeza dengan 'Urf Timur Tengah, dari segi kerangka konsepnya dan kaedah aplikasi yang lebih sesuai dengan realiti Malaysia semasa. ${ }^{56}$

3. Membangunkan prinsip dan standard mașlahah dalam tiga jenis, khususnya maslahah darüriyyah, hajjiyyah dan tahsiniyyah yang lebih sesuai dengan realiti Malaysia semasa. ${ }^{57}$

Ketujuh, KFS menetapkan model sistem fiqh Islam semasa perlu berasaskan kepada mazhab Syafi'i dalam bentuk yang bersifat selektif. Bertentangan dengan pandangan yang terlalu memandang negatif terhadap amalan bermazhab, kita sepatutnya mengamalkan sikap positif dan selektif terhadap amalan

55 Rahimin Affandi Abdul Rahim (2003), "Pengajian Sosial Dan H.ubungannya Dengan Pembinaan Hukum Islam Semasa: Satu Analisa”, dalam Rahminah Muharam (ed.), Isu-isu Sains Sosial dari perspektif Islam. Kota Kinabalu: Universiti Malaysia Sabah, hh. $1-34$.

56 Lihat sebagai contoh.nya tesis sarjana yang cuba mengupas tentang isu ini, yang dilakukan oleh. Noor Haslina Binti Osman (2003), Adat Melayu Sebagai Sumber Hukum: Penilaian Dari Perspektif Teori Al-'Urf Wa Al-Adah, (Tesis sarjana untuk Jabatan Fiqh dan Usul, APIUM).

57 Hal ini telah antara lainnya dikupas oleh Mahmood Zuhdi Ab Majid dan Paizah Ismail (2004), Pengantar Pengajian Syariah. Kuala Lumpur: Al-Baian Corporation Sdn Bhd, hh. 177-191. 
bermazhab. ${ }^{58}$ Secara kasarnya, mazhab adalah merupakan paradigma ${ }^{59}$ berfikir masyarakat Islam mengikut world-view dan kaedah syariah yang diasaskan oleh seseorang fuqaha tertentu. Ianya lahir daripada tradisi Islam sendiri dan bukannya berasal daripada pengaruh asing seperti didakwa oleh orientalis barat. ${ }^{60}$ Ianya merupakan kemuncak dari satu proses pembentukan worldview yang panjang. World-view adalah pandangan dunia, hidup, kepercayaan dan pemikiran yang berfungsi sebagai pemankin untuk segala perilaku manusia. ${ }^{61}$ Mengikut Hamid Zarkashi, world-view Islam adalah: visi tentang realiti dan kebenaran, berupa kesatuan pemikiran yang arsitektonik, yang berperanan sebagai asas yang tidak nampak (non-observable) bagi semua perilaku manusia, termasuk aktiviti ilmiah dan teknologi. Antara elemen asas untuk world-view Islam terdiri dari konsep tuhan, wahyu dan penciptaannya, psikologi manusia, ilmu, agama, kebebasan, nilai dan kebajikan dan kebahagiaan. Elemen-elemen inilah yang kemudiannya yang menentukan bentuk perubahan (change), perkembangan (development) dan kemajuan (progress) dalam Islam. ${ }^{62}$

58 Rahimin Affandi Abdul Rahim dan Noor Naemah Abdul Rahman (2005), "Pemikiran Reformasi Melayu Semasa: Satu Analisis", dalam Hashim Musa (ed.), Bahasa Dan Pemikiran Melayu. Kuala Lumpur: APMUM, h. 332-265.

59 Paradigma adalah satu set proposisi (rancangan usulan) yang menerangkan bagaimana dunia harus difahami. Ia berisikan sebuah pandangan dunia (world-view), suatu cara untuk memecahkan kerumitan dunia, yang memberitahu seseorang ilmuan tentang apa yang penting, apa yang sah dan apa yang bersesuaian dengan logik. Lihat Mona Abdul-Fadl (1989), Paradigms In Political Science Revisited. Herndon: AMSS \& IIIT.

60 T.J. De Boer (1994), The History Of Philosophy In Islam. Richmond: Curson press, hh. 28-29 \& 309.

61 Muhammad Abu Bakar (1993), "Pandangan Dunia, Ideologi Dan Kesarjanaan: Islam, Proses Sejarah Dan Rekonstruksi Realiti Sosial", dalam Tinta Kenangan, Sumbangan Sempena Persaraan Dan Perlantikan Naib Canselor, Profesor Datuk Mohd Taib Osman. Kuala Lumpur, hh. 307-309.

62 Hamid Fahmy Zarkasyi (2004), Tantangan Sekularisasi Dan Liberalisasi Di Dunia Islam. Surabaya: Penerbit Khairul Bayan, hh. 1-6. 
Berasaskan kepada paparan di atas, dapat kita rumuskan bahawa pegangan umat Islam terhadap mazhab Syafi'i bukanlah sesuatu amalan dan paradigma yang salah dalam pengamalan ajaran Islam, tetapi ianya merupakan formula yang bersifatflexible yang memberikan garis panduan terhadap setiap persoalan yang muncul dalam kehidupan manusia. Bagi konteks realiti Malaysia, amalan berpegang (taqlid) kepada mazhab Syafi'i boleh dianggap sebagai masih relevan lagi. Ianya dibuat kerana beberapa faktor yang utama;

1. Ianya menetapkan kalangan ulamak sebagai pentafsir utama kepada ajaran agama. Hal ini boleh dirujuk kepada keabsahan konsep taqlid dan ijtihad. Dalam konsep taqlid, ianya mengharuskan masyarakat awam untuk bertaqlid kepada seseorang mujtahid, berasaskan kepada nisbah ketidakmampuan seseorang awam untuk memahami ajaran agama Islam secara mendalam. ${ }^{63}$ Sikap yang hanya bergantung sepenuhnya kepada prinsip taqlid ini kemudiannya cuba dibataskan dengan penerimaan kepada konsep ijtihad dan tajdid.

2. Pendekatan ini ditetapkan bukannya bertujuan untuk memonopolikan usaha pentafsiran agama kepada golongan ulamak semata-mata, tetapi ianya dibuat bagi mengelakkan sebarang tindakan rakus daripada masyarakat awam yang jahil tentang prinsip asas Islam, melakukan tafsiran melulu dan boleh merosakkan nama baik Islam itu sendiri.

3. Faktor perpaduan dan keseragaman diperlukan bagi memastikan wujudnya kestabilan hidup sosio-politik umat Islam. Hal ini kemudiannya bakal memudahkan proses penguatkuasaan dan pentadbiran undang-undang Islam dijalankan. ${ }^{64} \mathrm{Hal}$ ini boleh dikatakan sebagai asas perpaduan umat Melayu sehingga tidak wujudnya perbalahan dan fanatik mazhab yang menimbulkan pertumpahan darah seperti mana

63 Rahimin Affandi Abdul Rahim (1993), "The Concept Of Ijma' In Islamic Law: A Comparative", dalam The Journal Of Hamdard Islamicus. Pakistan, v. 16, hh. 91-104.

64 Abdul Halim El-Muhammady (1992), "Ikhtilaf And Its Development In Malaysia", dalam International Islamic University Law Journal, v. 2 , no. 2 , hh. $54-55 \& 57$. 
berlaku di tempat-tempat lain. Cumanya, penekanan yang agak keterlaluan terhadap dominasi taqlid yang agak ketat ini dilihat bakal membuahkan hasil yang kurang sihat kepada perkembangan pemikiran hukum Islam itu sendiri. ${ }^{65} \mathrm{Hal}$ ini kemudiannya turut disedari sendiri oleh kalangan mufti di Malaysia yang disertakan pula dengan pelbagai usaha untuk menerapkan pendekatan reformism bagi menghadkan penggunaan taqlid secara berlebihan, khususnya di dalam metodologi pengeluaran sesuatu fatwa. ${ }^{66}$

4. Sikap pro mazhab ini bukan bermakna kita perlu terjebak dengan fenomena fanatik mazhab yang boleh menyumbang kepada ketertutupan minda, tetapi perlu berpegang kepada kerangka metodologi (manhaj) usuli sesuatu mazhab yang dilihat terbukti mampu menyelesaikan masalah hukum umat Islam. Kita tidak boleh memandang institusi Taqlid ini secara negatif keseluruhannya, memandangkan mengikut persepktif Tajdid yang tertanam di dalam hukum Islam itu sendiri, pelbagai perubahan yang diperlukan masih dibolehkan bagi menunjukkan sifat dinamisme syariah itu sendiri berhadapan dengan keperluan masyarakat. ${ }^{67}$ Maknanya, penerimaan konsep mazhab ini tidak membataskan amalan ijtihad itu dipraktikkan demi penyelesaian masalah umat Islam. Dewasa ini, teori yang mengatakan bahawa perundangan Islam telah tertutup dan beku selepas tertutupnya pintu ijtihad pada abab keempat hijrah telah mula dicabar. Sebaliknya seperti mana ditegaskan oleh Hallaq, proses dialektika antara sistem fiqh Islam dengan realiti sesuatu masyarakat masih lagi berlangsung di zaman Taqlid, kerana seseorang sarjana Islam yang melakukan aktiviti syarah dan Muhktasar terhadap karya imam mujtahid turut memasukkan komentar

65 Yusuf Qardawi (2004), Sanggahan Salah Tafsiran Islam, Abdul Rahman Rukaini (terj.). Kajang: Synergymate Sdn. Bhd, hh. 85-88.

66 Naemah Abd Rahman (2003), Fatwa Jemaah Ulamak Kelantan Tahun 1920an Hingga 1990an: Satu Analisis, (Tesis PhD, Jabatan Fiqh dan Usul), APIUM, hh. 183-185.

67 Amir Mualim (2006), Ijtihad Dan Legislasi Muslim Kontemporer. Yogyakarta: UII Press, hh. ix-xiii. 
pandangan mereka sendiri terhadap realiti yang berlaku di zaman mereka. ${ }^{68}$

5. Kita perlu mengamalkan sikap selektif terhadap pemikiran barat yang kerap menisbahkan penerimaan amalan bermazhab ini dengan istilah tradisionalisme, suatu nisbah yang hina. Paparan negatif ini sepatutnya tidak diterima secara melulu dan perlu dinilai secara berhikmah. ${ }^{69}$ Bagi penganut Islam, kita tidakboleh menganggapistilah tradisimembawa nisbahnegatif seperti difahami dalam dunia akademik barat. Sebaliknya, istilah tradisionalism ini patut dibanggakan kerana ianya merujuk kepada pemahaman dan penghayatan wahyu Allah di dalam kehidupan yang mencakupi tiga aspek; $;^{70}$ (i) $\mathrm{Al}$-Din, agama sebagai panduan untuk keseluruhan aspek kehidupan membabit tiga bentuk hubungan, dengan Allah, Mahkluk dan alam; (ii) Sunnah, amalan yang terbentuk dan berkembang berdasarkan model sacral (berasaskan wahyu) sehingga menjadi amalan kebudayaan masyarakat yang berpanjangan; (iii) Salsilah, mata rantai yang menghubungkan setiap zaman dan pemikiran kepada asasnya yang utama, wahyu Allah.

6. Kita patut menghargai precedent silam yang disumbangkan oleh mazhab Shafi'i di Malaysia. Penerimaan ini kemudiannya perlu dipelajari dan diperkembangkan dalam bentuk paradigma keilmuan moden yang lebih sesuai dengan realiti Malaysia semasa. Seperti mana direkodkan dalam catatan sejarah, walaupun kedatangan mazhab Syafi'i di Alam Melayu agak lewat berbanding dengan mazhab Syiah, namun kemudiannya mazhab ini telah mampu mengatasi mazhab Syiah dan meninggalkan pelbagai elemen positif jangka panjang kepada masyarakat Alam Melayu. Hal ini berlaku kerana beberapa faktor utama;

68 Hallaq (1996), "Ifta And Ijtihad In Sunni Legal Theory: A Development Account", dalam Islamic Legal Interpretation: Muftis And Their Fatwas. Cambridge: Harvard University press, hh. 33-43.

69 Rahimin Affandi Abd. Rahim (2000), “Etika Penyelidikan Islam : Satu Analisa", dalam Jurnal AFKAR, bil. 1, hh. 190-191.

70 S. Hossein Nasr (1990), Traditional Islam In The Modern World. London: Kegan Paul International, h. 13. 
a. Sifat mazhab Syafi'i yang berupa paradigma sentesis di antara pandangan Ahl Ray'dan ahli hadis. Ianya lebih adaptif dengan budaya tempatan Melayu. Mubaligh Syafi'i yang awal telah mengamalkan sikap mesra budaya yang mendapat dokongan penguasa politik serta kemudiannya mampu menyebarkan ajaran Islam secara cukup berkesan di Alam Melayu. ${ }^{71} \mathrm{Hal}$ ini boleh dilihat daripada kesannya di dalam Legal Digest Melayu seperti Hukum Kanun Melayu ${ }^{72}$ dan penyerapan nilai-nilai Islam di dalam sistem adat Melayu sehingga melahirkan ungkapan Adat bersendikan Hukum, hukum bersendikan Kitabullah. ${ }^{73}$

b. Gabungan antara paradigma sufi dan Fiqh (Neo-Sufism) di dalam mazhab Syafi'i - memberi kesan langsung kepada kepesatan proses pengislaman masyarakat Alam Melayu. ${ }^{74}$ Tidak seperti mazhab selain Syafi'i yang mengamalkan sikap negatif terhadap paradigma sufi, pendekatan ini tidak kedapatan dalam sejarah Alam Melayu. ${ }^{75}$

c. Fuqaha mazhab Syafi'i telah mengasaskan sistem pendidikan Islam yang lebih sistematik di rantau Alam

71 Rahimin Affandi Abd. Rahim (2006), "Ulamak Dan Paradigma Menanggani Kebudayaan Melayu", dalam Hashim Awang, Othman Yatim \& Nor Azita Che Din (ed.), Wacana Budaya. Kuala Lumpur : APMUM, hh. 55-80.

72 Rahimin Affandi Abd. Rahim (2003), "Pengamalan Ilmu Usul AlFiqh Di Dalam Sastera Undang-Undang Melayu: Satu Analisa", dalam Muhammad Mokhtar Hassan (ed.), Kesusasteraan Dan Undang-Undang. Kuala Lumpur: Penerbitan Akademi Pengajian Melayu, Universiti Malaya, hh. 158-179.

73 Siddiq Fadhil (2006), "Pertembungan Islam Dengan Budaya Peribumi: Pengalaman Alam Melayu", dalam Md Salleh Haji Ahmad (ed.), Hukum Islam Dan Budaya Tempatan. Kuala Lumpur: Jabatan Fiqh dan Usul, APIUM, hh. 142-145.

74 A.H. John (1961), "Muslim Mystics And Historical Writing", dalam Historians Of South-East Asia. London, hh. 40-41.

75 Che Zarrina Sa'ari \& Wan Suhaimi Wan Abdullah (2006), "Budaya Dan Etika Di Kalangan Ahli Tasauf Dan Pengaruhnya Terhadap Ketentuan Hukum", dalam Md Salleh Haji Ahmad (ed.), Hukum Islam Dan Budaya Tempatan. Kuala Lumpur: Jabatan Fiqh Dan Usul, APIUM, hh. 517-527. 
Melayu. ${ }^{76}$ Hal ini merujuk kepada pengenalan sistem Pondok yang mengandungi pasarana fizikal yang khusus, falsafah pengajian, struktur organisasi, susunan jadual waktu, kurikulum dan kaedah penilaian yang cukup sistematik. $^{77}$

\section{KESIMPULAN}

Sebagai kesimpulannya, dapat dirumuskan beberapa perkara yang utama iaitu; Pertama, proses pembangunan tamadun Islam di Malaysia tidak harus dihadkan penumpuannya kepada elemen material semata-mata, tetapi patut diperkasakan lagi dengan penjanaan idea dan paradigma pemikiran Islam yang bersifat progressif. Salah satu daripada elemen pemikiran Islam ini boleh dimasukkan dengan idea dan gagasan fiqh Islam semasa (Fiqh Malaysia). Ianya boleh dilihat sebagai mengisi program pengisian kemerdekaan dan pasca era kebangkitan semula Islam di Malaysia. Kedua, kertas kerja ini telah memperincikan dengan panjang lebar sumbangan bermakna yang boleh disumbangkan oleh gagasan fiqh semasa ini di dalam pembinaan tamadun Islam moden di Malaysia. Sebahagian besar daripada butiran sumbangan ini terletak di dalam kemampuan konsep fiqh semasa mengisi pemerkasaan pemikiran fiqh Islam di Malaysia. Selanjutnya, gagasan fiqh semasa ini perlu sama-sama disokong oleh kalangan ilmuan Islam di Malaysia, khususnya bagi memperlengkapkan lagi gagasan ini yang bakal diwariskan kepada generasi yang akan datang.

76 Abdul Latif Hamindong (1993), "Institusi Pondok Dalam Tradisi Budaya Ilmu", dalam Tamadun Melayu. Kuala Lumpur, v. 2, h. 748.

77 Abdullah Ishak (1995), Pendidikan Islam Dan Pengaruhnya Di Malaysia. Kuala Lumpur: DBP, hh. 212-218; Shafie Abu Bakar (1994), "Keilmuan Islam Dan Tradisi Pengajian Pondok", dalam Budi Kencana. Kuala Lumpur, hh. 104-111; Rahimin Affandi Abd. Rahim (2003), "Al-Quran Dan Peranan Ulamak Melayu Dalam Pemodenan Rantau Alam Melayu”, dalam Mohd Radzi Othman (ed.), Warisan Al-Quran Dan Peradaban Manusia Siri 1. Pulau Pinang: Penerbit Universiti Sains Malaysia, hh. 1-31. 